\title{
Reevaluating suitability estimates based on dynamics of cropland expansion in the Brazilian Amazon
}

\author{
Douglas C. Morton ${ }^{\mathrm{a}, *}$, Praveen Noojipady ${ }^{\mathrm{a}, \mathrm{b}, \mathrm{c}}$, Marcia M. Macedo ${ }^{\mathrm{d}}$, Holly Gibbs ${ }^{\mathrm{e}}$, \\ Daniel C. Victoria ${ }^{f}$, Edson L. Bolfe ${ }^{g}$ \\ a NASA Goddard Space Flight Center, Greenbelt, MD 20771, USA \\ ${ }^{\mathrm{b}}$ University of Maryland, College Park, MD 20742, USA \\ ${ }^{c}$ National Wildlife Federation-National Advocacy Center, Washington, D.C. 20006, USA \\ d Woods Hole Research Center, Falmouth, MA 02540, USA \\ e University of Wisconsin, Madison, WI 53706, USA \\ ${ }^{\mathrm{f}}$ Brazilian Agricultural Research Corporation-Embrapa Satellite Monitoring, Campinas, SP 13070-115, Brazil \\ g Brazilian Agricultural Research Corporation-Embrapa, Secretariat of Intelligence and Macrostrategy, Brasília, DF 70770-901, Brazil
}

\section{A R T I C L E I N F O}

\section{Article history:}

Received 29 June 2015

Received in revised form 2 February 2016

Accepted 8 February 2016

Available online 22 February 2016

\section{Keywords:}

Zoning

Utilization

Amazon

Soya

Potentially available cropland (PAC)

\begin{abstract}
A B S T R A C T
Agricultural suitability maps are a key input for land use zoning and projections of cropland expansion. Suitability assessments typically consider edaphic conditions, climate, crop characteristics, and sometimes incorporate accessibility to transportation and market infrastructure. However, correct weighting among these disparate factors is challenging, given rapid development of new crop varieties, irrigation, and road networks, as well as changing global demand for agricultural commodities. Here, we compared three independent assessments of cropland suitability to spatial and temporal dynamics of agricultural expansion in the Brazilian state of Mato Grosso during 2001-2012. We found that areas of recent cropland expansion identified using satellite data were generally designated as low to moderate suitability for rainfed crop production. Our analysis highlighted the abrupt nature of suitability boundaries, rather than smooth gradients of agricultural potential, with little additional cropland expansion beyond the extent of the flattest areas ( $0-2 \%$ slope). Satellite-based estimates of the interannual variability in the use of existing crop areas also provided an alternate means to assess suitability. On average, cropland areas in the Cerrado biome had higher utilization (84\%) than croplands in the Amazon region of northern Mato Grosso (74\%). Areas of more recent expansion had lower utilization than croplands established before 2002, providing empirical evidence for lower suitability or alternative management strategies (e.g., pasture-soya rotations) for lands undergoing more recent land use transitions. This unplanted reserve constitutes a large area of potentially available cropland (PAC) without further expansion, within the management limits imposed for pest management and fallow cycles. Using two key constraints on future cropland expansion, slope and restrictions on further deforestation of Amazon or Cerrado vegetation, we found little available flat land for further legal expansion of crop production in Mato Grosso. Dynamics of cropland expansion from more than a decade of satellite observations indicated narrow ranges of suitability criteria, restricting PAC under current policy conditions, and emphasizing the advantages of field-scale information to assess suitability and utilization.
\end{abstract}

Published by Elsevier Ltd.

\footnotetext{
* Corresponding author at: NASA Goddard Space Flight Center, Code 618, Greenbelt, MD 20771, USA. Fax: +1 3016146698.

E-mail addresses: douglas.morton@nasa.gov, douglas.morton@gmail.com (D.C. Morton).
}

\section{Introduction}

Global production of major commodity crops has risen steadily in recent decades, driven by a combination of intensification (e.g., Foley et al., 2011; Galford et al., 2008; Macedo et al., 2012; Spera et al., 2014; Zeng et al., 2014) and expansion of cropland area (e.g., Meyfroidt et al., 2014; Morton et al., 2006; Ramankutty and Foley, 1999). Recent expansion of commodity crop production has been concentrated in the global south, tilting the balance of the agro- 
economic playing field towards regions of soya and corn production in South America (Aide et al., 2013; Gasparri et al., 2015; Lambin et al., 2013). Increasing yields and expansion of croplands in the Cerrado and Amazon biomes contributed to Brazil's rise to prominence as a global leader in soya production.

Whether the trend of expanding crop production continues in Brazil depends on the amount of potentially available cropland (PAC, following Lambin et al., 2013). Suitability and PAC are related concepts; in this study, suitability for rainfed crop production reflects edaphic, climatic, and crop-specific characteristics, including access to markets. Estimates of PAC are typically a subset of all suitable lands that can be converted for rainfed agricultural based on a set of tradeoffs associated with expansion of agricultural production (Lambin et al., 2013). Tradeoffs for PAC may reflect decisions regarding conservation, greenhouse gas emissions, labor, or governance. Lambin et al. (2013) provided a series of examples where limits on PAC varied according to crop types and local circumstances across major regions of cropland expansion. Recent expansion of crop production in Brazil reflects underlying gradients of suitability and PAC based on the contemporary policy and economic context. Importantly, suitability and PAC vary in both space and time based on crop technology, market demands, and changing policies or governance (Fader et al., 2013; Lambin and Meyfroidt, 2011; Meyfroidt et al., 2013). We may expect, therefore, that estimates of both suitability and PAC diminish in relevance over time. However, few studies have considered the long-term accuracy or effective lifetime of cropland suitability assessments.

Market forces, environmental legislation, and enforcement efforts have changed the landscape of PAC in Brazil over the past decade. As market demand for Brazilian soybeans grew in Europe (Garrett et al., 2013; Nepstad et al., 2006) and China (Godar et al., 2015; Lambin and Meyfroidt, 2011; Lathuillière et al., 2014), it spurred increased production in Brazil, often accompanied by clearing of native Cerrado savannas and Amazon forests (Nepstad et al., 2014). The direct contribution from soya expansion to Amazon deforestation (Morton et al., 2006) led to the Soya Moratorium (SM), an industry initiative that has successfully reduced soya expansion from new Amazon deforestation since 2006 (Gibbs et al., 2015; Macedo et al., 2012; Nepstad et al., 2014). Recent changes in Brazil's Forest Code (FC) have also clarified the requirements for legal reserve areas on private properties (Brazil, 2012; Soares-Filho et al., 2014), further incentivizing cropland expansion on existing cleared areas (Gibbs et al., 2015; Macedo et al., 2012) and spurring the development of new agricultural frontiers in regions with a surplus of native vegetation relative to FC requirements for set-aside areas on private properties (Gibbs et al., 2015; Soares-Filho et al., 2014). The impact of these policy constraints on further cropland expansion in the Brazilian Amazon and Cerrado fundamentally depends on adequate enforcement of environmental laws (Gibbs et al., 2015) and whether suitable lands are abundant or scarce (Lambin et al., 2013).

The extent of suitable cropland has been debated for decades, beginning with the introduction of new management practices during the 'green revolution' (i.e., mechanization and fertilization) and concerns over population growth (e.g., Godfray et al., 2010; Lambin and Meyfroidt, 2011), and, more recently, attention to losses of ecosystem services and other tradeoffs associated with land use transitions (e.g., Foley et al., 2011; Green et al., 2005; Lambin et al., 2013; Rudel et al., 2009). Previous studies of crop suitability have analyzed constraints for crop production at regional (e.g., Jasinski et al., 2005; Soares-Filho et al., 2006; Vera-Diaz et al., 2008) and global scales (e.g., Hurtt et al., 2011; IIASA/FAO, 2011; Ramankutty and Foley, 1999). However, crop suitability changes dynamically in response to factors at the global, regional, and local scales. Regional variables such as governance, market demand, or climate often operate at large scales; they are necessary but not sufficient to support crop production. Local variables such as slope, soil type, or current land cover directly influence the viability of a given land area for crop production. Previous studies of cropland suitability in Brazil have often combined regional and local variables in their assessment (e.g., Jasinski et al., 2005; Vera-Diaz et al., 2008), blurring the spatial and temporal scales over which the suitability assessment is most appropriate.

Here, we compared previously published estimates of cropland suitability to satellite-based maps of cropland expansion over the past decade in the Brazilian state of Mato Grosso. Our analysis provided an empirical test of existing cropland suitability estimates based on the actual dynamics of recent cropland expansion. Annual time series of mechanized crop production derived from satellite data also yielded information on the longterm utilization of croplands, defined as the fraction of years in which crops were planted following conversion to cropland. Spatial and temporal variability in cropland utilization across the Cerrado and Amazon regions of Mato Grosso offered an alternate means to evaluate gradients of cropland suitability and the amount of PAC accessible through intensification. Finally, we estimated the remaining supply of PAC based on the observed cropland dynamics and current land use policies. Empirical data on cropland expansion under current climate and policy conditions supports a critical evaluation of suitability assessment efforts, including evidence for a more limited set of suitability criteria, sharp boundaries in suitability gradients that emerge from remote sensing data at the field scale, and short time scales over which suitability may be reasonably inferred.

\section{Materials and methods}

\subsection{Study region}

Rapid cropland expansion during the satellite era and a diversity of physical conditions make the Brazilian state of Mato Grosso an ideal case study to evaluate the accuracy and longevity of cropland suitability estimates. The state is large $\left(>900,000 \mathrm{~km}^{2}\right)$, with extensive crop production divided between the Amazon biome in the north and the Cerrado biome in the south and east. Cropland expansion since 2000 has been tracked using time series of moderate resolution satellite data (e.g., Morton et al., 2006; Rudorff et al., 2011), given the large size of soya farms in the state database of private properties ( mean $=1915$ ha; Gibbs et al., 2015).

\subsection{Policy context}

Mato Grosso is the largest soya-producing state in Brazil, often as part of a double cropping rotation with corn (Galford et al., 2010; Spera et al., 2014), with only 6\% of cropland area dedicated to largescale cotton and sugarcane production in 2013 (IBGE, 2013). Soya has also been a major driver of recent cropland expansion in the state (Gibbs et al., 2015; Macedo et al., 2012; Morton et al., 2006). These factors have given rise to specific policies for soya production in the region, including the SM to limit further expansion through Amazon deforestation (Gibbs et al., 2015; Macedo et al., 2012; Nepstad et al., 2014). The SM is an industry initiative to avoid purchasing soya from areas of recent Amazon deforestation (Macedo et al., 2012; Nepstad et al., 2014; Rudorff et al., 2011), and the SM was recently extended through May 2016 (Gibbs et al., 2015).

Brazil's FC governs conservation of native vegetation on all private properties (not just soya production), stipulating that $80 \%$ of each property in the Amazon and $20-35 \%$ in the Cerrado be set aside as a "legal reserve" (Brazil, 2012; Soares-Filho et al., 2014). 
The FC legislation was updated in 2012, changing conservation and restoration requirements for legal reserves and areas of permanent preservation (e.g., hill slopes and riparian areas), while introducing a new mechanism to facilitate trading of legal reserves to compensate for deforestation and bring private properties into compliance with the law (Soares-Filho et al., 2014). Although FC requirements apply to individual properties, in the absence of a unified land registry previous studies have used microwatersheds as a proxy for properties to estimate compliance with legal reserve requirements (Gibbs et al., 2015; Soares-Filho et al., 2014; Stickler et al., 2013). Although compliance with the FC and SM differentially impacts cropland expansion in the Amazon and Cerrado regions of Mato Grosso, these policies and enforcement efforts do not alter underlying gradients of crop suitability within each biome.

\subsection{Cropland expansion 2002-2012}

Time series of NASA satellite data were used to create annual cropland maps for Mato Grosso, Brazil. The classification approach identified large areas of mechanized crop production based on vegetation phenology (Gibbs et al., 2015), similar to previous studies of cropland dynamics in Brazil (Galford et al., 2008; Macedo et al., 2012; Morton et al., 2006; Rudorff et al., 2011). We used fourteen years of data from the Moderate Resolution Imaging Spectroradiometer (MODIS) sensor onboard the Terra satellite to generate annual cropland maps at $250 \mathrm{~m}$ spatial resolution. Classification of cropland areas considered Normalized Difference Vegetation Index (NDVI) data (MOD13Q1, Huete et al., 2002), using
October as the start of the crop year (day of year 273). The same classification approach was used to identify cropland areas in both the Amazon and Cerrado regions of Mato Grosso. Areas of existing crop production during 2000-2001 were separated from areas of cropland expansion. New cropland areas were limited to large patches $\left(\geq 1 \mathrm{~km}^{2}\right)$ classified as cropland in at least two successive years during 2002-2013. For this study, cropland areas were not further subdivided to identify specific crop types or separate single and double cropping rotations. Therefore, our analysis considers the spatial and temporal dynamics of all cropland, without specific treatment of soya or other cultivars. Cropland utilization was estimated as the fraction of planted years following conversion to mechanized agriculture, an indicator sometimes referred to as "cropping intensity" (de Beurs and Ioffe, 2013). Cropland maps compared favorably to validation data of cropland and noncropland cover types in Mato Grosso, with overall accuracies of 76\% and 94\% for field and air photos, respectively (Gibbs et al., 2015). A full description of the processing methods can be found in Gibbs et al. (2015).

\subsection{Suitability analysis}

Spatial and temporal patterns of cropland expansion and utilization were compared to three estimates of agricultural suitability for Mato Grosso. Jasinski et al. (2005) used land cover, slope, soils, precipitation, and distance from paved roads to assess cropland suitability. Data on crop production during 20002003 were included in this assessment. Therefore, our comparison
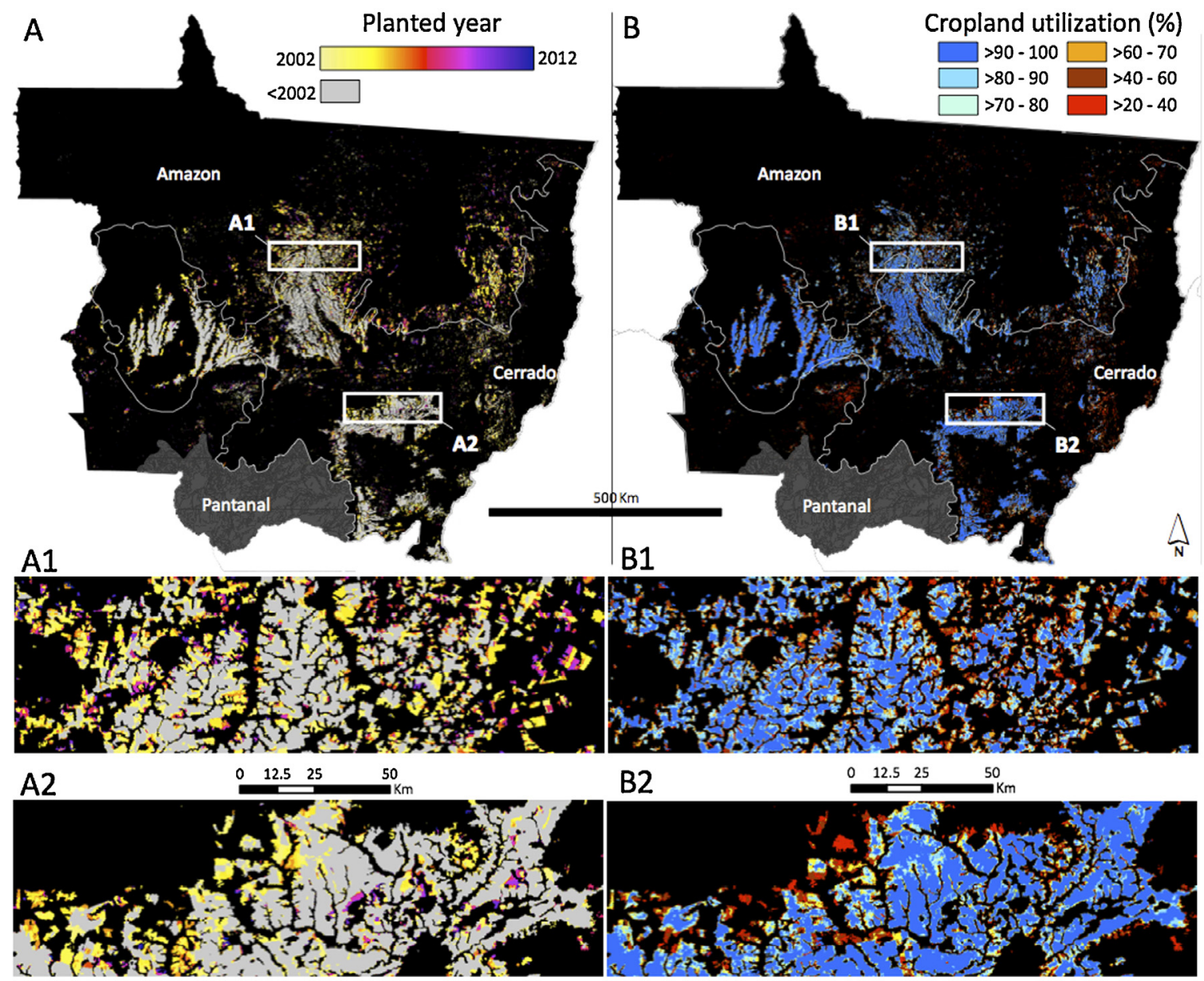

B2 $\begin{array}{llll}0 & 12.5 & 25 & 50 \\ & & & \\ & & \end{array}$

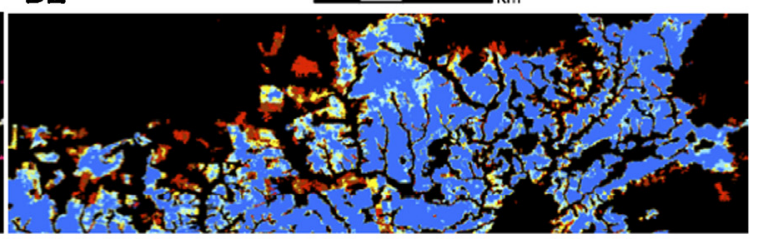

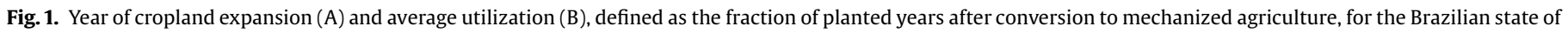
Mato Grosso (2001-2012). 
considered suitability estimates from Jasinski et al. (2005) for cropland expansion during 2004-2012. Soares-Filho et al. (2014) used slope $(<15 \%)$ and soils information to designate three levels of cropland suitability in Brazil (very appropriate, appropriate, and not suitable). This version of data (Soares-Filho et al., 2014) did not include constraints on crop production from climate, protected areas, or policies governing land use. Finally, we examined suitability data for rainfed crop production from Version 3 of the Global Agro-Ecological Zones (GAEZ) system (IIASA/FAO, 2011). The GAEZ analysis considered climate, soils, topography, inputs, and crop characteristics. We analyzed the suitability estimate for rainfed soya production with high inputs, given the widespread use of lime and fertilizers for mechanized agricultural production in Mato Grosso.

\subsection{Potentially available cropland (PAC)}

Based on the dynamics of recent cropland expansion, we estimated the area of PAC in Mato Grosso for further legal expansion of crop production using data on FC compliance and SM policies. We compared suitability estimates for areas in compliance with the FC from Jasinski et al. (2005),Soares-Filho et al. (2014), and IIASA/FAO (2011) to a simple approach based on slope. Our assessment identified large $\left(\geq 1 \mathrm{~km}^{2}\right)$ flat areas in microwatersheds with a surplus of remaining natural vegetation as required under the FC (Soares-Filho et al., 2014). Microwatersheds with insufficient reserves of natural vegetation indicate limited potential for cropland expansion (i.e., further clearing of native vegetation is likely prohibited, and some areas of existing agricultural production may need to be restored to comply with the FC). Slope information from $90 \mathrm{~m}$ resolution Shuttle Radar Topography Mission (SRTM) data (Farr et al., 2007) was averaged within each $250 \mathrm{~m}$ resolution cropland pixel. Data from (Hansen et al., 2013) were used to provide high-resolution (30m) estimates of cumulative deforestation through 2008 for Amazon regions of Mato Grosso, since the FC and SM consider areas deforested prior to 2008 differently from more recent deforestation (Gibbs et al., 2015). Differences between estimates of PAC under FC compliance and under both FC and SM constraints provide insight into the potential impact of current SM policies on cropland expansion in the Amazon region of Mato Grosso. The final assessment of PAC in 2013 also excluded protected areas, indigenous reserves, and
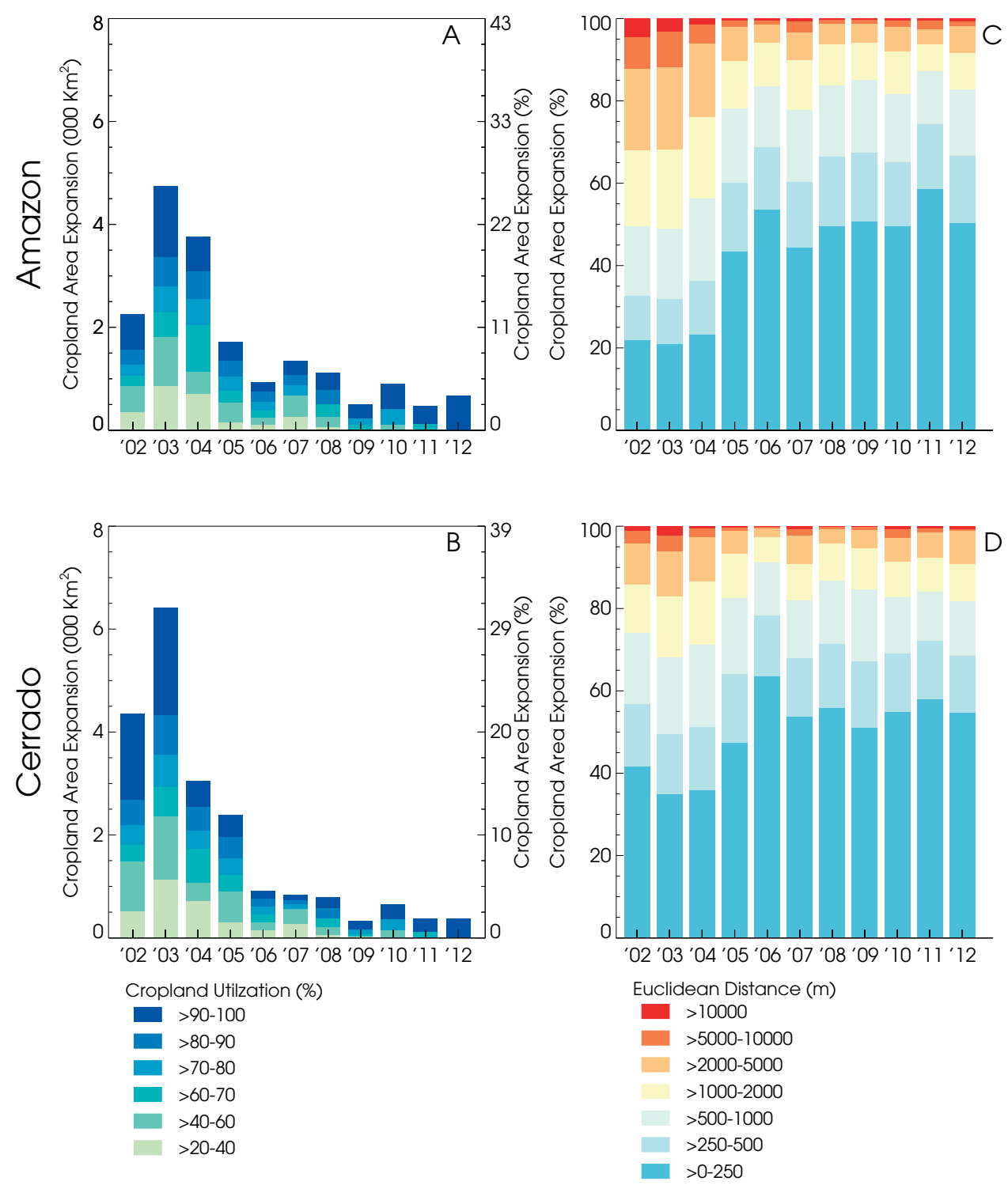

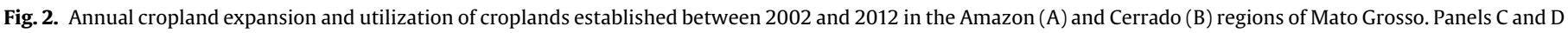
illustrate the distance between existing crop production and cropland expansion areas each year in the Amazon and Cerrado biomes, respectively. 
wetlands (Castello et al., 2013; Melack and Hess, 2011), including seasonally flooded areas within the Pantanal region in southern Mato Grosso.

\section{Results}

\subsection{Expansion}

Cropland expansion during 2001-2012 was evenly divided between the Amazon (51.9\%) and Cerrado (48.1\%) regions of Mato Grosso (Fig. 1). Annual rates of cropland expansion in Mato Grosso were highest before 2005. New croplands established in 2003 accounted for one quarter of total expansion in the Amazon region of northern Mato Grosso during 2001-2012, and roughly one third of all expansion in the Cerrado portion of the state during this period (Fig. 2). The 2003 expansion of soya in both biomes exceeded statewide expansion of soya from 2006-2012, highlighting the influence of peak soya prices (Morton et al., 2006), profitability (Macedo et al., 2012), and favorable exchange rates (Richards et al., 2012) on expansion dynamics.

Rates of cropland expansion fell sharply after 2006 in both biomes. Declining Amazon deforestation for soya production has received considerable attention, based on the industry's SM (Macedo et al., 2012; Gibbs et al., 2015) and government efforts to reduce illegal deforestation (Arima et al., 2014; INPE, 2015; Lapola et al., 2014; Nepstad et al., 2014). However, declining rates of cropland expansion in the Cerrado region of Mato Grosso have received less attention (Rocha et al., 2011). Total cropland expansion in the Amazon biome was more than double the new expansion in the Cerrado in the years following the Soya Moratorium (2006-2012), largely through expansion onto previously cleared land (Gibbs et al., 2015; Macedo et al., 2012). These dynamics suggest that there was a greater supply of suitable lands in the Amazon region of Mato Grosso during this period. It is also possible that demand shifted to new frontiers of soy expansion within the Cerrado biome, including the Matopiba region in northeastern Brazil (Brazil, 2015), reducing incentives for further expansion in Mato Grosso (Gibbs et al., 2015).

From 2002 to 2004, the majority of new cropland areas were established through expansion $>1 \mathrm{~km}$ from existing croplands, especially in the Amazon biome (Fig. 2). By 2006, most new cropland areas were a result of infilling and expansion at the margins of established zones of crop production $(\leq 500 \mathrm{~m})$. The short length scales and declining rates of new cropland expansion through 2012 further concentrated cropland in areas of established production. Regionally, most expansion after 2006 was concentrated in the Xingu River Basin in northeastern Mato Grosso and at the Amazon-Cerrado biome boundary in central Mato Grosso near the municipalities of Sinop, Tabaporã, and Tapurah (Box 1, Fig. 1). The combination of infilling and expansion dynamics outlined distinct regions of crop production-abrupt boundaries without further expansion beyond the extent of the flattest lands.

\subsection{Utilization}

Satellite data time series offer a unique perspective on patterns of crop management, including field-scale information on planting and fallow rotations. Rates of cropland utilization were higher in the Cerrado than the Amazon region of Mato Grosso (Fig. 3). On average, crop fields established before 2008 in the Cerrado were planted $84 \%$ of the time, or roughly 8 or 9 years out of 10 . Utilization of croplands in northern Mato Grosso was lower, with an average of $70 \%$ utilization for fields in the Amazon portion of the state. Differences in average utilization of cropland between the Cerrado and Amazon largely stem from older croplands (pre2002), as the average utilization of fields established between 2002

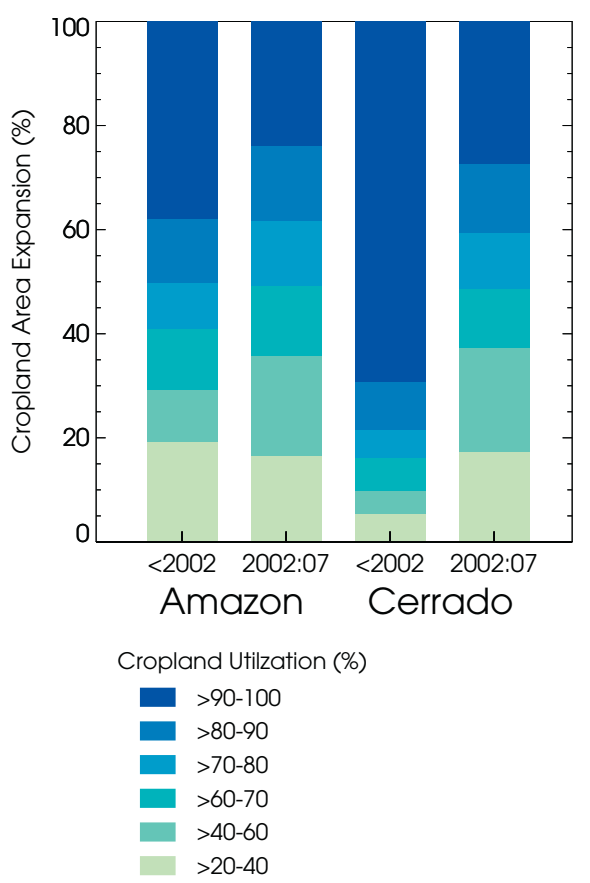

Fig. 3. Utilization of croplands established before 2002 and areas of recent cropland expansion (2002-2007) in the Amazon and Cerrado areas of Mato Grosso.

and 2007 was more similar across biomes (69\% Amazon, 74\% Cerrado). Utilization was not estimated for areas of most recent conversion, given the shorter time series of planting activity following conversion to cropland.

The spatial variability in cropland utilization provided additional information regarding management strategies and suitability (Fig. 1). Areas of established crop production by 2001 in the Cerrado had the highest utilization (90-100\% during 2001-2012). Two areas of production in the Cerrado stand out as regions with lower utilization. Lower utilization around Tangará da Serra in southwestern Mato Grosso may reflect the greater abundance of long-rotation crops such as sugarcane (IBGE, 2013), and the practice of a short rotation of annual crops that is grown before sugarcane is replanted ("reforma da canavial"). In southeastern Mato Grosso, crop production in Nova Xavantina also had lower utilization. In the Amazon region, intermittent cropland usage (20$60 \%$ utilization) was common in the eastern Xingu basin, an area of more recent expansion along the Amazon frontier. The transition process from ranching to crop production may partially explain lower utilization in this region, as lower productivity of initial planting (often rice, rather than soya) may not generate the seasonal amplitude in satellite data typical of higher productivity harvests in subsequent years. In addition, ranchers periodically lease individual fields to soya farmers, and this practice may contribute to variability in usage at the field scale (M. Macedo, Personal Observation).

\subsection{Suitability}

Since 2001, mechanized agriculture in the Cerrado and Amazon regions of Mato Grosso has expanded onto land with a broad range of estimated suitability. Despite varying degrees of specification for suitability criteria, recent cropland expansion included substantial areas of new production in regions considered to have low to moderate suitability (Fig. 4). The three estimates disagreed on the spatial patterns of suitability gradients in Mato Grosso. Notably, there was no recent expansion of cropland in several regions considered highly suitable, including the Araguaia River Basin 

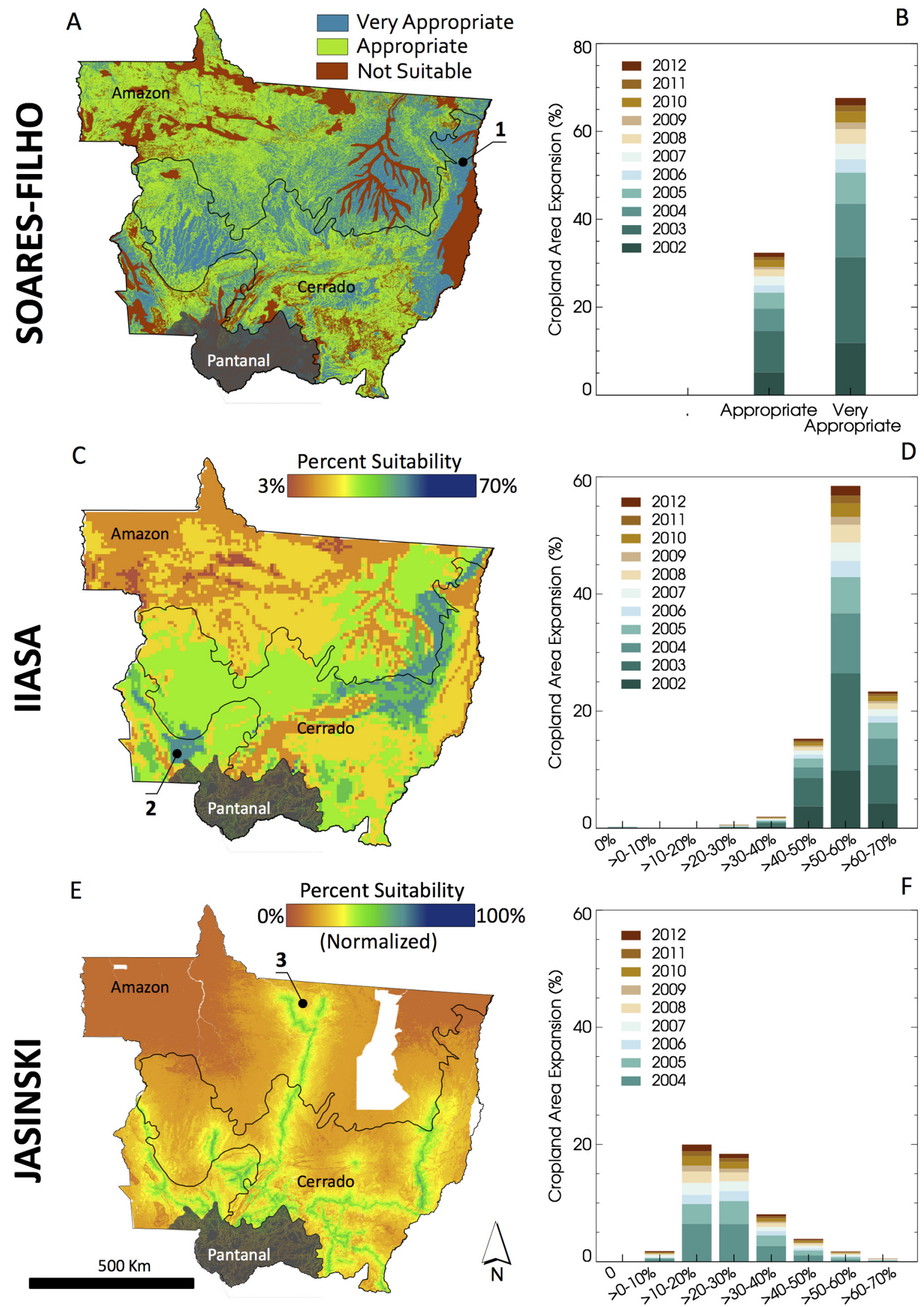

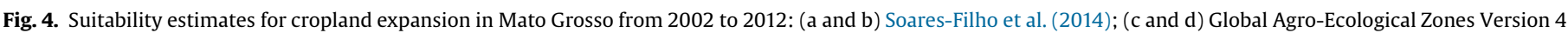
(IIASA/FAO, 2011); (e and f) Jasinski et al. (2005).

(Point \#1 in Fig. 4, Soares-Filho), southwest Mato Grosso near the municipality of Araputanga (Point \#2, IIASA-GAEZ and Jasinski), and Alta Floresta (Point \#3, Jasinski). Disparate spatial patterns of underlying suitability partially reflect the differences in input data; 
there are no "standard" variables for suitability estimates, one of the limits to any intercomparison of suitability maps.

Data from Soares-Filho et al. (2014) incorporated the fewest constraints. Slope and soil information proved important for the establishment of new cropland; no areas of cropland expansion were identified in regions considered unsuitable for crops. However, more than one-third of new cropland areas were established in regions considered appropriate as opposed to very appropriate for mechanized agriculture (Fig. 4).

The GAEZ database estimated highest suitability for rainfed soya production along the Amazon-Cerrado biome boundary. Most cropland expansion occurred in regions considered moderately suitable (50-60\%), with only one quarter of recent expansion in regions considered most suitable (60-70\%), including areas along the eastern limits of the Xingu River watershed. Two areas with substantial cropland in 2001 and further expansion in the following decade were considered to have low suitability in the GAEZ estimate. The central agricultural region between Sorriso and Sinop (Box 1, Fig. 1) and the southeastern zone of production near Primavera do Leste (Box 2, Fig. 1) were considered only $30-50 \%$ suitable, despite having some of the highest utilization of all cropland in Mato Grosso. The coarser spatial resolution of the GAEZ assessment may partially account for the broad gradients of estimated suitability, in contrast to the sharp boundaries delineated by the dynamics of recent cropland expansion.
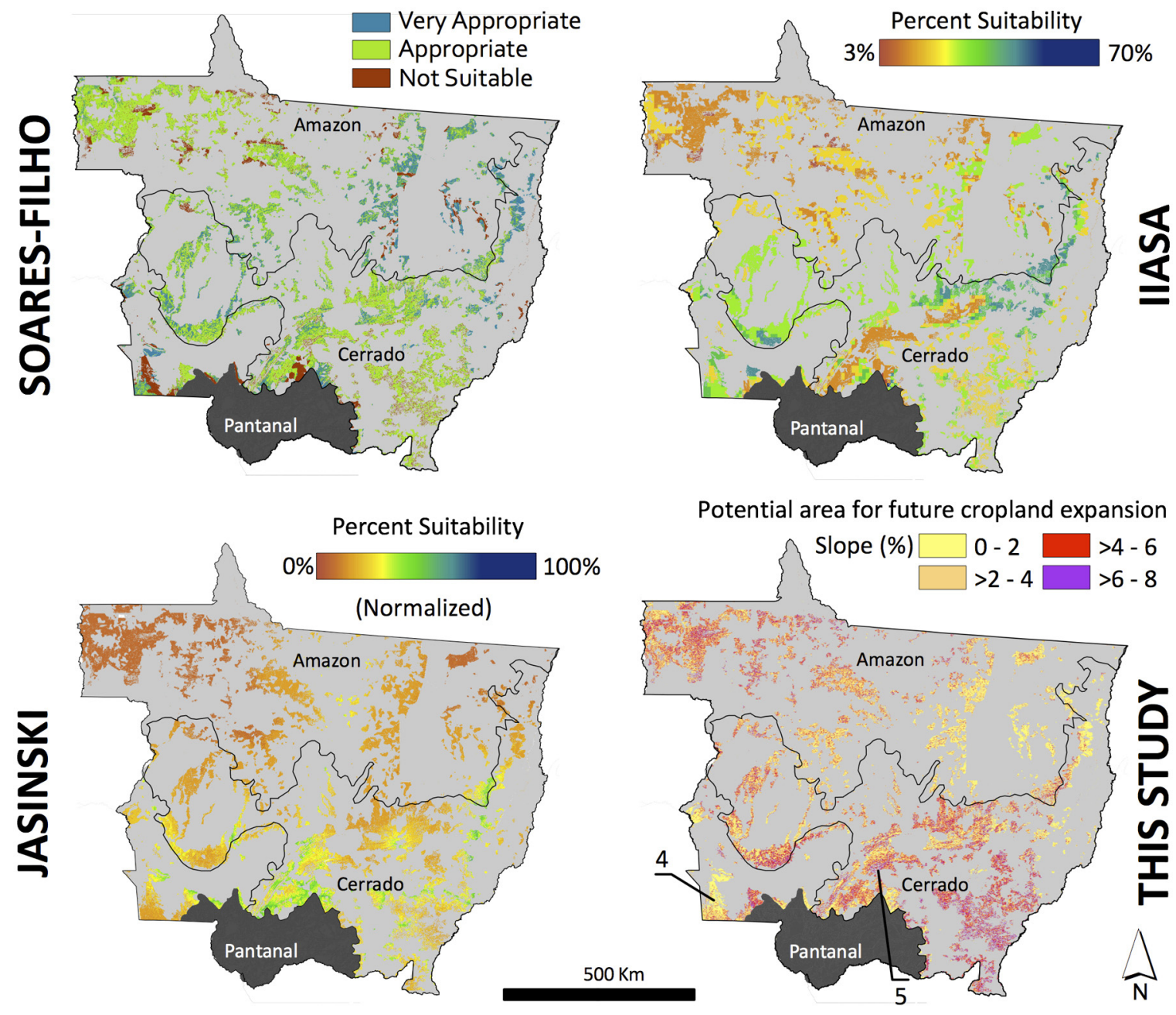

Potential area for future cropland expansion surplus of native vegetation in the Amazon and Cerrado regions outside of indigenous reserves and protected areas. Applying the same mask to the four different estimates of cropland suitability largely preserves the differences in underlying gradients of suitability, with regional differences in the areas of highest
Jasinski et al. (2005) estimated the lowest suitability for recent cropland expansion in Mato Grosso. The spatial pattern of roads in addition to slope, soils, and land cover information. Road infrastructure has changed markedly in Mato Grosso since 2003, ering the cost and complexity of market access across the state, thereby lowering the potential range of suitability based on distance constraints. Overall, Jasinski estimates for recent cropland expansion are skewed towards lower values of suitability. Lower Jasinski suitability values for more recent agricultural expansion confirm the importance of new regions of agricultural production in the state at the periphery of established corridors of production, with only modest infilling along circa 2003 transportation infrastructure after 2006 (Figs. 1 and 2).

\subsection{Potentially available cropland (PAC)}

Based on the FC requirements, the area for further legal expansion of crop production in Mato Grosso is limited (Fig. 5). The FC mask highlights the small number of microwatersheds with a
Slope (\%) $\square 0$ - $2 \square>4-6$

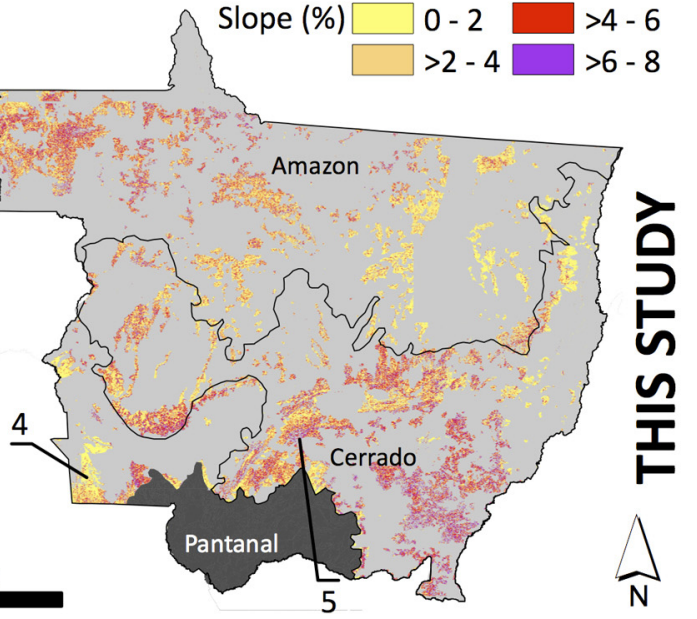

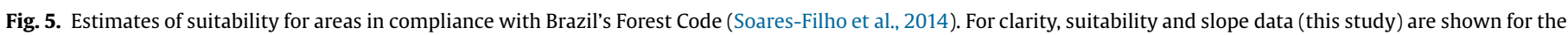
entire microwatershed, although only a portion of these areas could support legal cropland expansion. 


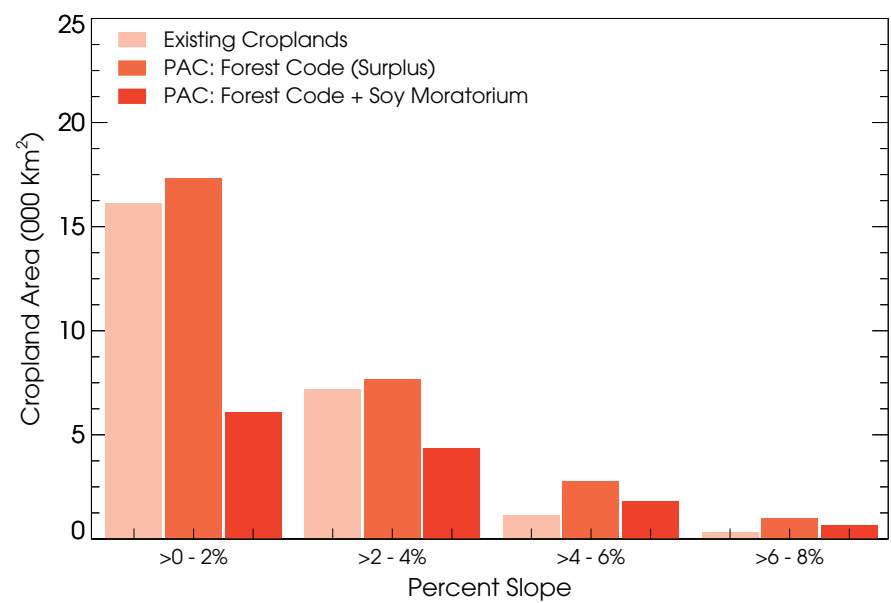

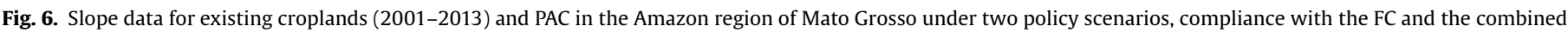
impact of SM and FC restrictions on cropland expansion.

suitability from northeast (Soares-Filho) to south-central Mato Grosso (Jasinski). The IIASA/FAO data suggest a narrow band of higher suitability along the Cerrado-Amazon biome boundary in central Mato Grosso, although much of this region has higher slope and more topographic relief (this study) than areas of existing production (Figs. 5 and 6). Several large regions with Intermediate slopes (2-6\%) surround the state capital, Cuiabá (Point \#5, Fig. 5), and southeastern portions of the state. However, these areas for potential expansion are geographically isolated from regions of existing crop production, indicating potential barriers to cropland expansion despite regional compliance with the FC. Importantly, the FC mask in Fig. 5 shows the full extent of the microwatershed, not the actual amount of surplus (Soares-Filho et al., 2014). Any further expansion of cropland in these areas would therefore be limited to only a portion of the total watershed extent under the FC ( $20 \%$ in the Amazon or $65 \%$ in the Cerrado biome). The full extent is shown in Fig. 5 to highlight the range of suitability conditions for any further expansion.

The combined influence of the SM and FC in the Amazon region of Mato Grosso limits PAC for soya production to land deforested prior to 2008 in microwatersheds with a surplus of native vegetation. The contrast between PAC estimates in Fig. 6 highlights how policy and economic factors can alter the landscape of PAC over decadal time scales. To date, crop production has expanded onto large areas with very flat terrain (0-2\% slope, Fig. 6). The SM reduces access to the flattest areas that might otherwise be available for cropland expansion under the FC (Fig. 6). Our analysis selected the flattest areas in microwatersheds with a surplus of Amazon forest, although not all of these flat regions may be suitable for crop production. Flat areas surround the Barbado River in southwest Mato Grosso (Point \#4, Fig. 5), yet crop production from 2001 to 2012 was very limited in this region, suggesting that soils, inundation, or other characteristics may render these flattest areas unsuitable for crop production. Other areas for legal cropland expansion have more complex terrain-a potential impediment to mechanized agricultural production (Fig. 6). Collectively, these caveats suggest that the contemporary PAC landscape in Mato Grosso is more limited than shown in Figs. 5 and 6.

\section{Discussion}

\subsection{Suitability and PAC}

This study provided an empirical test of cropland suitability estimates for one of the most active land use frontiers in the tropics. Overall, our analysis identified sharp gradients in crop suitability, defined predominantly by topography and soils, rather than infrastructure or climate. Differences between the pattern of recent cropland expansion and estimated gradients of suitability offer two key insights to improve future assessments. In general, no-go areas with lowest suitability were well defined; cropland did not expand into remote indigenous reserves (Jasinski et al., 2005), flooded wetlands (Soares-Filho et al., 2014), or steep slopes (GAEZ, IIASA/FAO, 2011). However, areas of highest suitability were not well captured in previous estimates, as the majority of cropland expansion in the past decade occurred in areas considered low to moderately suitable for crop production. These differences highlight the need for appropriate weighting of necessary and sufficient conditions for crop production, with careful attention to technology, market, and policy changes that alter the underlying gradients of crop suitability and PAC.

High-resolution land cover information in this study provided new insights regarding suitability constraints for cropland expansion. Sharp boundaries in suitability overwhelmed broad regional conditions for crop production, with little expansion beyond the extent of flat lands, even for the oldest regions of crop production in the state. Spatial resolution may also account for some of the disparity between suitability estimates and cropland expansion. Satellite data provided contemporary, field-scale information to evaluate the patterns and processes of crop expansion across the state of Mato Grosso. Coarse resolution suitability estimates, often with climate data as the lowest common denominator, blur the sharp boundaries in site characteristics that constrain land use activities. Thus, the coarse spatial resolution of many suitability datasets may limit their applicability in regions with fine-scale spatial heterogeneity in topography or soils.

Dynamics of cropland expansion and utilization in Mato Grosso over the past decade are consistent with a more a limited amount of PAC than estimated in previous studies (Gibbs et al., 2015; Jasinski et al., 2005; Lambin et al., 2013; Soares-Filho et al., 2014), especially if future expansion is compliant with FC legislation (Gibbs et al., 2015; Soares-Filho et al., 2014). Full implementation of the FC (Soares-Filho et al., 2014), including efforts to demarcate and register rural properties in a web-based national land registry system (SICAR), will offer new mechanisms to evaluate compliance with environmental laws at the farm scale (Gibbs et al., 2015). Combined with existing capacity for monitoring deforestation in near-real time (INPE, 2015; Morton et al., 2005), efforts by industry, government, and non-governmental organizations to improve accountability are more transparent and timely. The net effect of 
these policies, monitoring, and enforcement efforts is a reduction in PAC in Mato Grosso.

Pressure for cropland expansion in Mato Grosso has also been released through expansion of new agricultural frontiers (Gibbs et al., 2015), including Cerrado regions of Maranhão, Tocantins, Piauí, and Bahia states known as "Matopiba." The May 2015 release of the Matopiba Agricultural Development Plan (Brazil, 2015) highlights the regional and national interest in further expansion of crop production in this region. New frontiers in the Cerrado biome underscore the potential for national and global crop production dynamics to impact producers in Mato Grosso. Whether expansion in Matopiba represents true "leakage" (i.e., producers avoiding more stringent environmental governance in the Brazilian Amazon) or simply a new agricultural frontier (higher suitability, more PAC) is an area of ongoing research. Regardless, expanding production elsewhere in Brazil alters the conditions for crop production in Mato Grosso, adding to the influence of global commodity markets on regional cropland dynamics (Fader et al., 2013; Godar et al., 2015; Lambin and Meyfroidt, 2011).

Estimates of PAC in this study are closely tied to the contemporary policy context. Efforts to evaluate the impact of FC compliance in this study may overestimate the area of PAC. Fig. 5 highlights the range of suitability conditions within the entire microwatershed where cropland expansion could occur, since the precise location of future expansion cannot be determined. For the Amazon region, estimates of the combined influence of the SM and FC excluded further legal deforestation for all crop production, yet the current moratorium applies only to soya production, and then only through May 2016 (Gibbs et al., 2015). The estimates of PAC for Cerrado and Amazon areas shown in Figs. 5 and 6 are likely to be short lived in their utility. Near-term decisions on the lifetime of the SM (Gibbs et al., 2015), completion of the land registry (SICAR), and development of a state-wide reserve trading scheme (CRA) (Soares-Filho et al., 2014) will undoubtedly redraw the map of PAC in the coming years.

\subsection{Cropland utilization}

The ability to estimate cropland utilization is a unique advantage of satellite monitoring. Cropland utilization can be difficult to determine from agricultural census data on planted area, especially in regions with multiple cropping cycles. Areas of more recent expansion in both the Cerrado and Amazon regions of Mato Grosso had substantially lower utilization, consistent with other evidence for cropland expansion into more marginal areas (Spera et al., 2014). Management decisions at the field scale may also reflect a diversification of production strategies, including soya-corn-pasture rotations that are highly productive and responsive to market conditions but appear as lower utilization, or pest management strategies through rotation or fallowing of individual fields. Regional or interannual variability in these planting strategies is an important area for future research.

Increasing utilization is an alternate pathway for intensification of crop production in the region, beyond higher yields achieved with double cropping (Galford et al., 2010; Spera et al., 2014) or replacement of extensive land uses with more intensive practices (e.g., Lapola et al., 2014; Macedo et al., 2012; Strassburg et al., 2014). However, increasing utilization of croplands in Mato Grosso faces four important constraints. First, expansion of croplands into more marginal areas, particularly in terms of climate (Spera et al., 2014), may limit the viability of double cropping to years with sufficient rainfall. Second, pest management is a key factor that limits utilization at the field scale. Regional restrictions to reduce soybean rust, nematodes, or other pathogens set the upper bound for utilization of fields in a soya rotation. Third, lower utilization may be important for regional agricultural management, where fallow rotations support cattle production beyond an individual field or farm, leading to a lower limit for overall utilization. The use of crop fields to seasonally supplement cattle diets with crop residues is a widespread but poorly quantified aspect of ranching. Finally, on-farm infrastructure (e.g., grain storage) and off-farm factors (e.g., transportation and market access) also influence planting and management decisions at the field scale. With the addition of economic and crop-specific management data, detailed studies may identify important patterns of utilization at the field scale. Disentangling these factors is one goal of continued satellitebased monitoring of the spatial and temporal variability in cropland utilization.

\subsection{Limitations}

Satellite data offer distinct advantages for understanding cropland suitability, including the opportunity to evaluate spatial and temporal dynamics of crop production and field-scale management decisions. However, satellite-based estimates of cropland area or management also have important limitations. Satellite detection of crop phenology may be less accurate in the early years of production, when vegetation productivity is often lower. The spatial resolution of satellite monitoring data can also limit the ability to identify small fields or fine-scale variability in crop management. Mato Grosso is particularly suitable for monitoring efforts with moderate resolution satellite data, based on large field sizes and a limited number of crop varieties (Morton et al., 2006), but agricultural regions with more fine-scale heterogeneity will be difficult to monitor with these approaches. Ongoing improvements to satellite monitoring efforts in support of environmental governance, precision agriculture, and research activities will continue to advance the capabilities of satellitebased monitoring of crop dynamics in near-real time. This up-todate information is critical to assess the likelihood of land use changes, the effectiveness of policy and economic instruments, and the market and climate sensitivity of regional crop production.

\section{Conclusions}

Satellite data time series capture information about cropland management at the field scale. Utilization is not well known for many regions, since regional crop statistics cannot be easily disaggregated to characterize planting practices. For Mato Grosso, estimates of utilization and suitability provided contrasting views of recent agricultural expansion. Although croplands established before 2002 had higher utilization than areas of cropland expansion during 2002-2007, estimates of agriculture suitability were similar for these areas. Overall, previous assessments of crop suitability in the region overestimated the extent of suitable lands. Cropland expansion in recent years targeted lands with narrower ranges of site conditions, highlighting the abrupt nature of suitability boundaries for mechanized crop production. Few areas with similar characteristics remain for future legal expansion of cropland in Mato Grosso. Continued compliance with Brazil's FC and the industry SM would therefore concentrate new soya production in the Cerrado biome in areas with more topographic complexity. Looking ahead, continued satellite monitoring of cropland dynamics in Mato Grosso could generate unique insights into the evolution of frontier landscapes, including the development and impact of regional public policies and farm-level responses to market and climate variability.

\section{Acknowledgements}

Funding for this study was provided by NASA, the Norwegian Agency for Development Cooperation (NORAD, Grants QZA-0465 
and QZA-13/0075), and a Science Without Borders Visiting Scientist Fellowship (D.C. Morton), administered by the Brazilian National Counsel of Scientific and Technological Development (CNPq) for the Brazilian Ministry of Science, Technology, and Innovation (MCTI). We are grateful to Drs. Britaldo Soares-Filho and Laura Hess for their willingness to share data on crop suitability and land cover.

\section{References}

Aide, T.M., Clark, M.L., Grau, H.R., López-Carr, D., Levy, M.A., Redo, D., BonillaMoheno, M., Riner, G., Andrade-Núñez, M.J., Muñiz, M., 2013. Deforestation and reforestation of Latin America and the Caribbean (2001-2010). Biotropica 45, 262-271.

Arima, E.Y., Barreto, P., Araújo, E., Soares-Filho, B., 2014. Public policies can reduce tropical deforestation: lessons and challenges from Brazil. Land Use Policy 41, 465-473.

Brazil, 2012. Brazil's Forest Code, Law n. 12.651-05/25/2012, Brasilia, DF.

Brazil, 2015. Agricultural Development Plan Matopiba, Law n. 8.447-05/06/2015, Brasilia, DF.

Castello, L., McGrath, D.G., Hess, L.L., Coe, M.T., Lefebvre, P.A., Petry, P., Macedo, M.N. Reno, V.F., Arantes, C.C., 2013. The vulnerability of Amazon freshwater ecosystems. Conserv. Lett. 6, 217-229.

de Beurs, K.M., Ioffe, G., 2013. Use of Landsat and MODIS data to remotely estimate Russia's sown area. J. Land Use Sci. 9, 377-401.

Fader, M., Gerten, D., Krause, M., Lucht, W., Cramer, W., 2013. Spatial decoupling of agricultural production and consumption: quantifying dependences of countries on food imports due to domestic land and water constraints. Environ. Res. Lett. 8.

Farr, T.G., Rosen, P.A., Caro, E., Crippen, R., Duren, R., Hensley, S., Kobrick, M., Paller, M., Rodriguez, E., Roth, L., Seal, D., Shaffer, S., Shimada, J., Umland, J., Werner, M., Oskin, M., Burbank, D., Alsdorf, D., 2007. The shuttle radar topography mission. Rev. Geophys. 45.

Foley, J.A., Ramankutty, N., Brauman, K.A., Cassidy, E.S., Gerber, J.S., Johnston, M. Mueller, N.D., O'Connell, C., Ray, D.K., West, P.C., Balzer, C., Bennett, E.M., Carpenter, S.R., Hill, J., Monfreda, C., Polasky, S., Rockstrom, J., Sheehan, J., Siebert, S., Tilman, D., Zaks, D.P.M., 2011. Solutions for a cultivated planet. Nature 478, 337-342.

Galford, G.L., Melillo, J., Mustard, J.F., Cerri, C.E.P., Cerri, C.C., 2010. The Amazon frontier of land-use change: croplands and consequences for greenhouse gas emissions. Earth Interact. 14

Galford, G.L., Mustard, J.F., Melillo, J., Gendrin, A., Cerri, C.C., Cerri, C.E.P., 2008 Wavelet analysis of MODIS time series to detect expansion and intensification of row-crop agriculture in Brazil. Remote Sens, Environ. 112, 576-587.

Garrett, R.D., Rueda, X., Lambin, E.F., 2013. Globalization's unexpected impact on soybean production in South America: linkages between preferences for nongenetically modified crops, eco-certifications, and land use. Environ. Res. Lett. 8 , 044055.

Gasparri, N.I., Grau, H.R., Sacchi, L.V., 2015. Determinants of the spatial distribution of cultivated land in the North Argentine Dry Chaco in a multi-decadal study. J. Arid Environ. 123, 31-39.

Gibbs, H.K., Rausch, L., Munger, J., Schelly, I., Morton, D.C., Noojipady, P., SoaresFilho, B., Barreto, P., Micol, L., Walker, N.F., 2015. Brazil’s soy moratorium. Science 347, 377-378.

Godar, J., Persson, U.M., Tizado, E.J., Meyfroidt, P., 2015. Towards more accurate and policy relevant footprint analyses: tracing fine-scale socio-environmental impacts of production to consumption. Ecol. Econ. 112, 25-35.

Godfray, H.C.J., Beddington, J.R. Crute, I.R., Haddad, L., Lawrence, D., Muir, J.F., Pretty, J., Robinson, S., Thomas, S.M., Toulmin, C., 2010. Food security: the challenge of feeding 9 billion people. Science 327, 812-818.

Green, R.E., Cornell, S.J., Scharlemann, J.P.W., Balmford, A., 2005. Farming and the fate of wild nature. Science 307, 550-555.

Hansen, M.C., Potapov, P.V., Moore, R., Hancher, M., Turubanova, S.A., Tyukavina, A. Thau, D., Stehman, S.V., Goetz, S.J., Loveland, T.R., Kommareddy, A., Egorov, A., Chini, L., Justice, C.O., Townshend, J.R.G., 2013. High-resolution global maps of 21st-century forest cover change. Science 342, 850-853.

Huete, A.R., Didan, K., Miura, T., Rodriguez, E.P., Gao, X., Ferreira, L.G., 2002 Overview of the radiometric and biophysical performance of the MODIS vegetation indices. Remote Sens. Environ. 83, 195-213.

Hurtt, G.C., Chini, L.P., Frolking, S., Betts, R.A., Feddema, J., Fischer, G., Fisk, J.P., Hibbard, K., Houghton, R.A., Janetos, A., Jones, C.D., Kindermann, G., Kinoshita, T. Klein Goldewijk, K., Riahi, K., Shevliakova, E., Smith, S., Stehfest, E., Thomson, A. Thornton, P., Vuuren, D.P., Wang, Y.P., 2011. Harmonization of land-use scenarios for the period 1500-2100: 600 years of global gridded annual land-use transitions, wood harvest, and resulting secondary lands. Clim. Change 109, $117-161$

IBGE,, 2013. Produção Agrícola Municipal. Instituto Brasileiro de Geografia e Estatística.

IIASA/FAO, 2011. Global Agro-Ecological Zones (GAEZ v3.0). In: IIASA (Ed.) Laxenburg, Austra and FAO, Rome, Italy.

INPE, 2015. Sistema DETER: Detecção de Desmatamento em Tempo Real. Instituto Nacional de Pesquisas Espaciais.
Jasinski, E.W., Morton, D.C., DeFries, R. S., Shimabukuro, YE Anderson, L. O, Hansen, M.C., 2005. Physical landscape correlates of the expansion of mechanized agriculture in Mato Grosso, Brazil. Earth Interact. 9, 18.

Lambin, E.F., Gibbs, H.K., Ferreira, L., Grau, R., Mayaux, P., Meyfroidt, P., Morton, D.C. Rudel, T.K., Gasparri, I., Munger, J., 2013. Estimating the world's potentially available cropland using a bottom-up approach. Glob. Environ. Change 23, 892 901.

Lambin, E.F., Meyfroidt, P., 2011. Global land use change, economic globalization, and the looming land scarcity. Proc. Natl. Acad. Sci. 108, 3465-3472.

Lapola, D.M., Martinelli, L.A., Peres, C.A., Ometto, J.P.H.B., Ferreira, M.E., Nobre, C.A., Aguiar, A.P.D., Bustamante, M.M.C., Cardoso, M.F., Costa, M.H., Joly, C.A., Leite, C. C., Moutinho, P., Sampaio, G., Strassburg, B.B.N., Vieira, I.C.G., 2014. Pervasive transition of the Brazilian land-use system. Nat. Clim. Change 4, 27-35.

Lathuillière, M.J., Johnson, M.S., Galford, G.L., Couto, E.G., 2014. Environmental footprints show China and Europe's evolving resource appropriation for soybean production in Mato Grosso, Brazil. Environ. Res. Lett. 9, 074001.

Macedo, M.N., DeFries, R.S., Morton, D.C., Stickler, C.M., Galford, G.L., Shimabukuro, Y.E., 2012. Decoupling of deforestation and soy production in the southern Amazon during the late 2000s. Proc. Natl. Acad. Sci. 109 (4), 1341-1346.

Melack, J.M., Hess, L.L., 2011. Remote sensing of the distribution and extent of wetlands in the Amazon Basin. In: Junk, W.J., Piedade, M.T.F., Wittmann, F., Schöngart, J., Parolin, P. (Eds.), Amazonian Floodplain Forests. Springer, Netherlands, pp. 43-59.

Meyfroidt, P., Carlson, K.M., Fagan, M.E., Victor, H.G.-V., Macedo, M.N., Curran, L.M., DeFries, R.S., Dyer, G.A., Gibbs, H.K., Lambin, E.F., Morton, D.C., Robiglio, V., 2014 Multiple pathways of commodity crop expansion in tropical forest landscapes. Environ. Res. Lett. 9, 074012.

Meyfroidt, P., Lambin, E.F., Erb, K.-H., Hertel, T.W., 2013. Globalization of land use: distant drivers of land change and geographic displacement of land use. Curr. Opin. Environ. Sustain. 5, 438-444.

Morton, D.C., DeFries, R.S., Shimabukuro, Y.E., Anderson, L.O., Arai, E., Espirito-Santo, F.d.B., Freitas, R., Morisette, J., 2006. Cropland expansion changes deforestation dynamics in the southern Brazilian Amazon. Proc. Natl. Acad. Sci. 103, 1463714641

Morton, D.C., DeFries, R.S., Shimabukuro, Y.E., Anderson, L.O., del bon Espírito-Santo, F. Hansen, M.C. Carroll, M., 2005. Rapid assessment of annual deforestation in the Brazilian Amazon using MODIS data. Earth Interact. 9, 22.

Nepstad, D., McGrath, D., Stickler, C., Alencar, A., Azevedo, A., Swette, B., Bezerra, T., DiGiano, M., Shimada, J., Seroa da Motta, R., Armijo, E., Castello, L., Brando, P., Hansen, M.C., McGrath-Horn, M., Carvalho, O., Hess, L., 2014. Slowing Amazon deforestation through public policy and interventions in beef and soy supply chains. Science 344, 1118-1123.

Nepstad, D.C., Stickler, C.M., Almeida, O.T., 2006. Globalization of the Amazon soy and beef industries: opportunities for conservation. Conserv. Biol. 20, 15951603.

Ramankutty, N., Foley, J.A., 1999. Estimating historical changes in global land cover: croplands from 1700 to 1992. Glob. Biogeochem. Cycles 13, 997-1027.

Richards, P.D., Myers, R.J., Swinton, S.M., Walker, R.T., 2012. Exchange rates, soybean supply response, and deforestation in South America. Glob. Environ. ChangeHum. Policy Dimens. 22, 454-462.

Rocha, G.F., Ferreira, L.G., Ferreira, N.C., Ferreira, M.E., 2011. DETECÇAO DE DESMATAMENTOS NO BIOMA CERRADO ENTRE 2002 E 2009: PADROES, TEND ENCIAS E IMPACTOS. Revista Brasileira de Cartografia 63, 341-349.

Rudel, T.K., Schneider, L., Uriarte, M., Turner, B.L., DeFries, R., Lawrence, D. Geoghegan, J., Hecht, S., Ickowitz, A., Lambin, E.F., Birkenholtz, T., Baptista, S., Grau, R., 2009. Agricultural intensification and changes in cultivated areas, 1970-2005. Proc. Natl. Acad. Sci. 106, 20675-20680.

Rudorff, B.F.T., Adami, M., Aguiar, D.A., Moreira, M.A., Mello, M.P., Fabiani, L., Amaral, D.F., Pires, B.M., 2011. The soy moratorium in the Amazon biome monitored by remote sensing images. Remote Sens. 3, 185.

Soares-Filho, B., Rajão, R., Macedo, M., Carneiro, A., Costa, W., Coe, M., Rodrigues, H., Alencar, A., 2014. Cracking Brazil's Forest Code. Science 344, 363-364.

Soares-Filho, B.S., Nepstad, D.C., Curran, L.M., Cerqueira, G.C., Garcia, R.A., Ramos, C. A., Voll, E., McDonald, A., Lefebre, P., Schlesinger, P., 2006. Modeling conservation in the Amazon basin. Nature 440, 520-523.

Spera, S., Avery, S.C., Leah, K.V., Jack, F.M., Bernardo, F.R., Joel, R., Marcos, A., 2014. Recent cropping frequency, expansion, and abandonment in Mato Grosso, Brazil had selective land characteristics. Environ. Res. Lett. 9, 064010.

Stickler, C.M., Nepstad, D.C., Azevedo, A.A., McGrath, D.G., 2013. Defending public interests in private lands: compliance, costs and potential environmental consequences of the Brazilian Forest Code in Mato Grosso. Philos. Trans. R. Soc. B-Biol. Sci. 368.

Strassburg, B.B.N., Latawiec, A.E., Barioni, L.G., Nobre, C.A., da Silva, V.P., Valentim, J. F., Vianna, M., Assad, E.D., 2014. When enough should be enough: improving the use of current agricultural lands could meet production demands and spare natural habitats in Brazil. Glob. Environ. Change 28, 84-97.

Vera-Diaz, M.d.C., Kaufmann, R.K., Nepstad, D.C., Schlesinger, P., 2008. An interdisciplinary model of soybean yield in the Amazon Basin: the climatic, edaphic, and economic determinants. Ecol. Econ. 65, 420-431.

Zeng, N., Zhao, F., Collatz, G.J., Kalnay, E., Salawitch, R.J., West, T.O., Guanter, L., 2014. Agricultural green revolution as a driver of increasing atmospheric $\mathrm{CO}_{2}$ seasonal amplitude. Nature 515, 394-397. 